\title{
MENINGKATKAN KEMAMPUAN BERHITUNG PERMULAAN DENGAN PERMAINAN BALOK ANGKA PADA ANAK KELOMPOK B
}

\author{
Mudiyarsih \\ TK Dharma Wanita 1 Ngadimulyo Kedu Temanggung \\ Email : asihmudiyarsih@gmail.com
}

\begin{abstract}
Abstrak
Tujuan dari penelitian ini adalah untuk mengetahui bahwa dengan permainan balok angka dapat meningkatkan kemampuan berhitung permulaan anak Kelompok B TK Dharma Wanita 1 Ngadimulyo Kedu Temanggung Semester II Tahun Pelajaran 2017/2018, untuk mengetahui besarnya peningkatan kemampuan berhitung permulaan dengan permainan balok angka pada anak Kelompok B TK Dharma Wanita 1 Ngadimulyo Kedu Temanggung Semester II Tahun Pelajaran 2017/2018.

Subyek penelitian ini adalah peserta didik Kelompok B TK Dharma Wanita 1 Ngadimulyo berjumlah 20 anak. Metode pengumpulan data yang digunakan adalah observasi, penugasan, dokumentasi dan wawancara. Berdasarkan hasil penelitian, maka dapat disimpulkan bahwa dengan permainan balok angka dapat meningkatkan kemampuan berhitung permulaan anak Kelompok B TK Dharma Wanita 1 Ngadimulyo Kedu Temanggung Semester II Tahun Pelajaran 2017/2018. Hal ini dibuktikan dengan adanya peningkatan kemampuan berhitung permulaan anak sebelum tindakan hanya mencapai $15 \%$, kemudian setelah diadakan perbaikan pada Siklus I meningkat menjadi 45\%, dan Siklus II menjadi $85 \%$, telah memenuhi persentase maksimum yang telah ditentukan yaitu $80 \%$. Persentase keberhasilan yang dicapai dari kondisi pra siklus sampai dengan Siklus II sebesar 70\%. Keberhasilan ini ditandai dengan anak mampu mengenal konsep bilangan 1-10, mengenal konsep banyak sedikit dan mampu menyebutkan hasil penambahan dan pengurangan.
\end{abstract}

Kata kunci : berhitung permulaan, permainan, balok angka

Abstract
The purpose of this study was to find out that with number beam games can improve the numeracy skills of the beginning of the group Dharma Wanita 1 TK B Ngadimulyo Kedu Temanggung Semester II 2017/2018 Academic Year, to find out the magnitude of the increase in numeracy skills with number digit games in Group B children Dharma Wanita 1 Kindergarten Ngadimulyo Kedu Temanggung Semester II 2017/2018 Academic Year.

The subjects of this study were 20 students in the Dharma Wanita 1 Kindergarten Kindergarten Group B. Data collection methods used are observation, assignment, documentation and interviews. Based on the results of the study, it can be concluded that with the number beam game can improve the numeracy ability of the beginning of the child Group Dharma Wanita 1 TK B Ngadimulyo Kedu Temanggung Semester II 2017/2018 Academic Year. This is evidenced by the increase in the ability to count the beginning of the child before the action only reached $15 \%$, then after the improvement in Cycle I increased to 45\%, and Cycle II to $85 \%$, has met the maximum percentage that has been determined that is $80 \%$. The percentage of success achieved from pre-cycle conditions to Cycle II is $70 \%$. This success is characterized by children being able to recognize the concepts of numbers 1-10, recognizing many concepts a little and being able to mention the results of additions and subtractions.

Keywords: beginning counting, games, number blocks

(C) 2019 Mudiyarsih

Under the license CC BY-SA 4.0

http://jurnal.upmk.ac.id/index.php/pelitapaud 


\section{PENDAHULUAN}

Perkembangan kognitif merupakan perkembangan yang terkait dengan kemampuan berpikir seseorang. Bisa juga diartikan sebagai perkembangan intelektual. Terjadinya proses perkembangan ini dipengaruhi oleh kematangan otak yang mampu menunjukkan fungsinya secara baik. Kognisi merupakan bagian intelek yang merujuk pada penerimaan, penafsiran, pemikiran, pengingatan, pengkhayalan, pengambilan keputusan, dan penalaran (Muhammad Fadillah, 2012: 41-42).

Dalam perkembangan kognitif pada anak sangat dipengaruhi oleh pertumbuhan sel otak dan perkembangan hubungan antar sel otak. Dari teori Piaget yang membicarakan perkembangan kognitif, perkembangan dari tahapan sensorimotor (0-2 tahun), praoperasional (2-7 tahun), operasional konkret (7-12 tahun), dan operasional formal (12-15 tahun), maka perkembangan kognitif anak masa prasekolah berada pada tahap praoperasional (Soemiarti Padmonodewo, 2003:19).

Di lingkungan sekitar kita banyak sekali hal yang selalu berhubungan dengan matematika. Begitu juga dengan dunia anak TK yang sering kita lihat adalah matematika dalam porsi yang masih sangat sederhana yang merupakan tingkat pencapaian perkembangan dalam pembelajaran berhitung permulaan yang meliputi anak mampu membilang angka, menuliskan angka, menjumlahkan bendabenda, dan lain-lain. Pembelajaran berhitung tersebut tentunya akan berguna bagi anak karena pada kehidupan selanjutnya mereka akan lebih sering bersentuhan dengan beberapa konsep tersebut dalam berbagai permasalahan yang lebih komplek.

Dalam pembelajaran di TK, berhitung merupakan suatu kegiatan yang kurang menarik, membosankan dan masih terasa sulit bagi anak TK. Hal ini disebabkan oleh beberapa faktor baik dari guru, peserta didik maupun sumber belajar dan metode yang digunakan sebagai pendukungnya.

Berkaitan dengan pengembangan kemampuan daya pikir yang termasuk dalam aspek perkembangan kognitif, berhitung di TK dalam pelaksanaanya harus dilakukan dengan cara yang menarik, bervariasi dan dalam suasana bermain yang menyenangkan. Metode berhitung diperlukan untuk menumbuhkembangkan keterampilan berhitung yang sangat diperlukan dalam kehidupan sehari-hari, terutama konsep bilangan yang merupakan juga dasar bagi pengembangan 
kemampuan matematika maupun kesiapan untuk mengikuti pendidikan selanjutnya (Depdiknas, 2007).

Beberapa permasalahan yang sering muncul terkait dengan pembelajaran berhitung permulaan pada anak kelompok B TK Dharma Wanita 1 Ngadimulyo Kedu adalah metode pembelajaran yang kurang tepat atau kurang sesuai dengan karakteristik, kebutuhan dan minat anak. Anak cenderung lebih asyik bercerita atau bermain dengan teman daripada mengikuti pembelajaran yang disampaikan oleh guru. Selain itu, media pembelajaran yang kurang menarik atau kurang sesuai dengan minat, kebutuhan dan tahap perkembangan anak. Dalam pembelajaran yang dilaksanakan terbukti masih banyak menggunakan LKA (Lembar Kerja Anak). Dengan menggunakan LKA, anak menghitung gambar benda, menebalkan angka atau menuliskan angkanya secara langsung. Hal ini tentu saja mengakibatkan anak menjadi tidak antusias dan mudah bosan dalam mengikuti proses pembelajaran. Kurangnya kreatifitas guru dalam memanfaatkan bahan atau media yang ada di lingkungan sekitar yang digunakan untuk membantu proses pembelajaran dan penggunaan metode yang tidak sesuai dengan minat, kebutuhan dan tahap perkembangan anak yang menyebabkan kurangnya minat anak pada saat pembelajaran berhitung, anak lebih senang berbicara sendiri daripada mendengarkan penjelasan dari guru dan suasana kelas menjadi kurang kondusif, anak tidak mau mengerjakan tugas yang diberikan oleh guru, dan anak belum mampu dan tidak paham dalam melakukan proses berhitung sederhana.

Berdasarkan pengamatan terhadap pengembangan kognitif di Kelompok B TK Dharma Wanita 1 Ngadimulyo Kedu ditemukan adanya masalah rendahnya tingkat kemampuan berhitung permulaan pada anak. Hal ini ditandai pada setiap diberikan kegiatan berhitung, jumlah anak yang bisa menghitung dengan kriteria berkembang sesuai harapan hanya 3 anak atau $15 \%$ dari 20 anak yang ada di kelompok B, penilaian dengan kriteria mulai berkembang 2 anak atau 10\%, dan sisanya sebanyak 15 anak atau $75 \%$ belum berkembang, pada saat guru memberikan kegiatan pengembangan berhitung permulaan menggunakan angka 1-10 anakanak kurang menyenangi kegiatan tersebut, dalam kegiatan pengenalan konsep bilangan, anak-anak kelompok B hanya bisa menyebutkan urutan bilangannya saja, anak masih belum paham atau belum mengerti simbol angka 1-10. 
Atas dasar permasalahan yang telah ditemukan dalam kelas berkaitan dengan kemampuan berhitung pada kelompok B tersebut, maka peneliti melakukan sebuah Penelitian Tindakan Kelas sebagai upaya perbaikan pelaksanaan pembelajaran berhitung permulaan dengan mengambil judul "Meningkatkan Kemampuan Berhitung Permulaan dengan Permainan Balok Angka pada Anak Kelompok B TK Dharma Wanita 1 Ngadimulyo Kedu Temanggung Semester II Tahun Pelajaran 2017/2018".

\section{METODE PENELITIAN}

\section{Tempat Penelitian}

Lokasi penelitian tindakan kelas ini dilakukan di TK Dharma Wanita 1 Ngadimulyo Kedu Temanggung.

\section{Waktu Penelitian}

Penelitin tindakan kelas ini dilaksanakan pada Semester II tahun pelajaran 2017/2018, tepatnya pada bulan Maret 2018.

\section{Subjek Penelitian}

Subyek penelitian merupakan peserta didik yang dikenai tindakan yaitu semua anak kelompok B TK Dharma Wanita 1 Ngadimulyo Kedu Temanggung yang berjumlah 20 anak yang terdiri dari 8 anak laki-laki dan 12 anak perempuan dengan melibatkan 1 orang guru sebagai observer. Data dan Sumber Data
Sumber data dibedakan atas data primer dan data sekunder. Sumber data primer adalah objek yang diobservasi langsung yang dilakukan di Kelompok B TK Dharma Wanita 1 Ngadimulyo dan para informan atau pemberi informasi yang diwawancarai yaitu anak Kelompok B dan guru TK Dharma Wanita 1 Ngadimulyo. Sumber data sekunder berupa dokumentasi dan arsip-arsip resmi yang dapat mendukung hasil penelitian yang diperoleh dari hasil raport, daftar penilaian, dan daftar hadir anak.

\section{Teknik dan Alat Pengumpulan Data}

Observasi

Pengamatan dilakukan sebelum sampai dengan sesudah diberikan tindakan penelitian dan kolaborator mencatat semua hal yang diperlukan maupun yang terjadi selama pelakasanaan tindakan berlangsung. Kolaborator mencatat semua hasil kegiatan yang dicapai anak dalam lembar observasi yang disediakan.

Penugasan

Anak diberi kesempatan oleh peneliti untuk melakukan kegiatan pembelajaran berhitung. Pada saat pembelajaran berlangsung anak dapat melaksanakan kegiatan berhitung permulaan dengan permainan balok angka yang telah diajarkan terlebih dahulu.

Dokumentasi 
Dokumentasi dilakukan saat observasi, pengambilan foto-foto tersebut bertujuan agar data yang diperoleh yakni yang berupa fakta-fakta peristiwa proses pembelajaran dapat optimal, sehingga dapat dijadikan sebagai bukti, selain itu dapat dijadikan sebagai bahan evaluasi terhadap perkembangan kognitif anak. Hasil kegiatan dari pelaksanaan tindakan didokumentasikan agar terlihat jelas dan akurat. Pelaksanaan tindakan ini didokumentasikan dalam bentuk foto.

Wawancara

Wawancara digunakan untuk menggali data secara mendalam. Wawancara dalam penelitian ini digunakan untuk memperoleh informasi tentang pembelajaran kegiatan harian terutama dalam meningkatkan kemampuan berhitung permulaan anak Kelompok B TK Dharma Wanita 1 Ngadimulyo dan tanggapan guru sebelum dan sesudah selesai diadakan tindakan dengan permainan balok angka.

\section{Analisa Data}

Dari penelitian tindakan kelas ini, data dianalisis sejak tindakan pembelajaran dilakukan dan dikembangkan selama proses refleksi sampai proses penyusunan laporan. Dalam analisis data ini dilakukan perbandingan antara Siklus I dan Siklus II, maka analisis data ini menggunakan deskriptif komparatif, yaitu mendeskripsikan kondisi lapangan yang dapat dilihat pada gambaran obyek penelitian yang telah diperoleh dengan tujuan untuk mengetahui peningkatan kemampuan berhitung permulaan anak. Kemudian data tersebut dikomparasikan dengan tinjauan pustaka sebagai tolok ukur penelitian sehingga dapat diambil kesimpulan. Metode analisis komporatif diambil berdasarkan hasil observasi terhadap peningkatan kemampuan berhitung permulaan anak, serta diambil berdasarkan hasil per siklus dibandingkan dengan indikator kinerja per siklus. Langkah-langkah analisis komporatif adalah :

Memberikan nilai pada setiap hasil pengamatan.

Membuat tabulasi nilai observasi kemampuan berhitung permulaan dengan permainan balok angka.

Menghitung persentase pencapaian peningkatan kemampuan setiap anak dengan cara :

Jumlah skor butir pengamatan anak x $100 \%$ Skor maksimum

Menghitung hasil rata-rata pencapaian dengan skor maksimum pada setiap siklus yang telah ditentukan.

Membandingkan hasil persentase pencapaian pada setiap anak dengan 
persentase keberhasilan pada setiap siklus yang telah ditentukan.

Indikator Keberhasilan

Indikator keberhasilan ini ditandai dengan perubahan pada proses berhitung yang dilakukan oleh anak meningkat, perubahan menuju ke arah perbaikan. Keberhasilan akan terlihat apabila hasil kegiatan anak dalam membilang dan mengoperasikan penjumlahan dan pengurangan 1-10 dengan kriteria keberhasilan dalam penelitian ini mencapai $80 \%$ anak mendapat nilai dengan kriteria baik.

Tabel 1. Indikator Keberhasilan Anak

\begin{tabular}{|c|c|c|c|c|}
\hline \multirow[t]{2}{*}{ Indikator } & \multicolumn{4}{|c|}{ Penilaian } \\
\hline & $\mathrm{BB}$ & $\begin{array}{c}\mathrm{M} \\
\mathrm{B}\end{array}$ & BSH & BSB \\
\hline $\begin{array}{l}\text { Anak mampu } \\
\text { mengenal konsep } \\
\text { bilangan 1-10 } \\
\text { Anak mampu } \\
\text { mengenal konsep } \\
\text { banyak sedikit } \\
\text { Anak mampu } \\
\text { menyebut-kan hasil } \\
\text { penambahan dan } \\
\text { pengurangan }\end{array}$ & & & & \\
\hline
\end{tabular}

Keterangan :

BB : Belum Berkembang

MB : Mulai Berkembang

BSH : Berkembang Sesuai Harapan

BSB : Berkembang Sangat Baik

\section{Prosedur Penelitian}

Perencanaan Tindakan

Mengidentifikasi masalah yang ada di dalam kelas yang akan menjadi topik yang perlu perhatian khusus dan merupakan topik dalam penelitian ini.

Membuat Rencana Pelaksanaan Pembelajaran Harian (RPPH), materi yang diajarkan tentunya sesuai dengan kurikulum yang dituangkan dalam RPPH. RPPH ini berguna sebagai pedoman guru dalam melaksanakan kegiatan pengembangan kognitif.

Guru mempersiapkan lembar observasi mengenai partisipasi anak. Mempersiapkan sarana dan media yang akan digunakan, pelaksanaan kegiatan serta sarana pendukung lainnya. Mengevaluasi kegiatan, agar dapat mengetahui keadaan anak dan kesulitan dalam melaksanakan kegiatan pengembangan kognitif. Materi yang ditekankan pada penelitian ini meliputi kegiatan berhitung permulaan dengan permainan balok angka.

Pelaksanaan Tindakan

Pelaksana tindakan ini dilakukan selama pembelajaran berlangsung dengan dibantu guru untuk mengamati keterlibatan atau partisipasi anak saat melaksanakan kegiatan berhitung. Untuk selanjutnya hasil dari kegiatan anak diamati dan dicatat sebagai hasil pengamatan untuk dievaluasi dan direfleksi bersama kolaborator, sehingga dapat menentukan, merencakan pertemuan berikutnya kearah peningkatan. 
Tindakan berupa pelaksanaan rencana pembelajaran yang telah disiapkan sebelumnya. Tindakan yang dilakukan peneliti sesuai dengan perencanaan yang sudah disusun. Tindakan ini dilaksanakan dengan tiga tahap yaitu pendahuluan, inti, dan penutup.

Observasi

Kegiatan yang dilakukan adalah observasi terhadap tindakan dengan cara mengamati, mencatat secara teliti dengan menggunakan lembar observasi yang telah disiapkan. Observasi dilakukan sebelum kegiatan, saat kegiatan berlangsung dan setelah selesai kegiatan. Observasi ini dilakukan dengan menggunakan lembar observasi.

Refleksi

Selanjutnya data-data yang sudah diperoleh dari observasi baik sebelum maupun setelah kegiatan tersebut kemudian dicatat, dikumpulkan dan dianalisis serta didiskusikan bersama kolaborator. Setiap akhir pertemuan dalam setiap siklus peneliti dan kolaborator menganalisis apakah pelaksanaan tindakan sudah sesuai perncanaan, apakah format observasi perlu ditambah dan sebagainya, sehingga hasil analisis tadi dapat digunakan untuk menentukan langkah selanjutnya. Tujuan dari diskusi tersebut adalah untuk mengevaluasi hasil tindakan, masalah yang muncul dan segala hal yang berkaitan dengan tindakan yang dilakukan. Setelah selesai berdiskusi peneliti mencari jalan keluarnya agar dibuat rencana perbaikan pada tahap kegiatan selanjutnya.

Pada penelitian tindakan kelas yang dilaksanakan ini, setelah mengkaji, menganalisis, dan mengevaluasi pada Siklus I peneliti dan guru bekerjasama lagi untuk menindaklanjutinya dengan melakukan penelitian di Siklus II. Pada Siklus ke II nanti akan diketahui juga mengenai hasil apakah sudah maksimal atau belum. Apabila pada Siklus II hasil yang diharapkan belum maksimal, maka penelitian dapat dilanjutkan pada siklus berikutnya sampai dengan hasil yang diharapkan optimal sesuai dengan indikator yang telah ditetapkan.

HASIL PENELITIAN DAN PEMBAHASAN

\section{Hasil Penelitian}

Observasi pada kondisi awal didapatkan data bahwa untuk pembelajaran aspek perkembangan kognitif khususnya berhitung permulaan dari 20 peserta anak, hanya 3 anak (15\%) yang menunjukkan kemampuan berhitung berkembang sesuai harapan, 2 anak (10\%) mulai berkembang, dan $15(75 \%)$ anak belum berkembang. Hasil tersebut dapat dilihat pada tabel berikut : 
Siklus I

Tabel 1 Kondisi Awal Sebelum Penelitian

\begin{tabular}{ccc}
\hline Penilaian & $\begin{array}{c}\text { Jumlah } \\
\text { Anak }\end{array}$ & Persentase \\
\hline BB & 15 & $75 \%$ \\
MB & 2 & $10 \%$ \\
BSH & 3 & $15 \%$ \\
BSB & 0 & $0 \%$ \\
\hline
\end{tabular}

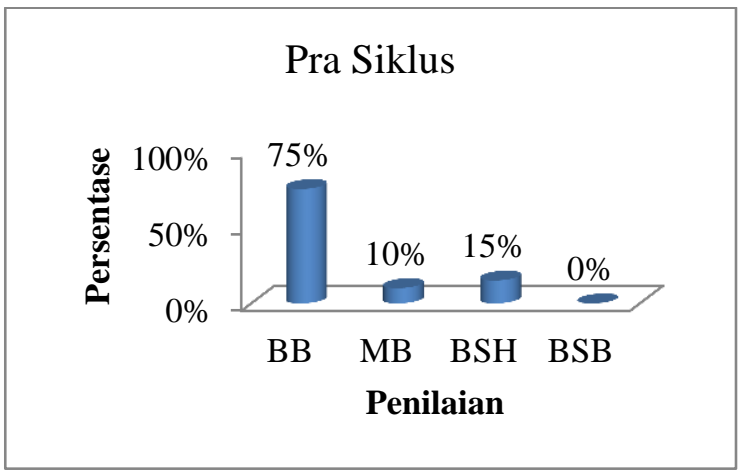

Gambar 1. Grafik Kemampuan Berhitung Permulaan Anak Kondisi Pra Siklus

Dari tabel dan grafik di atas dapat diketahui bahwa kemampuan berhitung permulaan anak belum berkembang baik. Hal ini dapat dilihat dari hasil rekapitulasi data kemampuan berhitung permulaan anak Kelompok B yang memperoleh kriteria penilaian berkembang sesuai harapan sebesar $15 \%$. Perolehan rata-rata di atas belum mencapai target keberhasilan yang diinginkan yaitu dengan kriteria berkembang sesuai harapan dan persentase mencapai $80 \%$. Hal ini yang menjadikan landasan peneliti untuk meningkatkan kemampuan berhitung permulaan pada anak Kelompok B TK Dharma Wanita 1 Ngadimulyo melalui permainan balok angka.
Dari beberapa pertemuan yang telah dilaksanakan pada Siklus I diperoleh hasil observasi pertemuan pertama dengan menggunakan instrumen lembar observasi menyebutkan bahwa kemampuan berhitung permulaan pada anak Kelompok B sesuai data yang diperoleh adalah anak yang mendapat kriteria belum berkembang 12 anak (60\%), kriteria penilaian mulai berkembang 3 anak (15\%), kriteria penilaian berkembang sesuai harapan 5 anak (25\%). Terjadi peningkatan dari kondisi pra siklus yaitu 3 anak atau 15\% menjadi 5 anak atau $25 \%$ pada pertemuan pertama Siklus I.

Hasil analisis observasi terhadap peningkatan berhitung permulaan anak pada Siklus I pertemuan kedua adalah 9 anak (45\%) dengan penilaian berkembang sesuai harapan, 4 anak (20\%) mulai berkembang, dan 7 anak (35\%) dengan kriteria penilaian belum berkembang dan masih memerlukan bimbingan.

Berdasarkan hasil pengamatan dalam penelitian melalui permainan balok angka untuk meningkatkan kemampuan berhitung permulaan pada anak kelompok B TK Dharma Wanita 1 Ngadimulyo Siklus I, terlihat perkembangan sebagian anak sudah mampu mengurutkan angka 1-10 dan menunjukkan kumpulan benda yang 
sama dan tidak sama walaupun belum semua anak berhasil melakukannya dengan baik.

Tabel 2. Peningkatan Kemampuan Berhitung Permulaan Anak Siklus I

\begin{tabular}{|c|c|c|c|c|}
\hline \multirow[b]{2}{*}{ Penilaian } & \multicolumn{2}{|c|}{ Pertemuan I } & \multicolumn{2}{|c|}{ Pertemuan II } \\
\hline & $\begin{array}{c}\text { Jumlah } \\
\text { anak }\end{array}$ & $\%$ & $\begin{array}{c}\text { Jumlah } \\
\text { anak }\end{array}$ & $\%$ \\
\hline$\overline{B B}$ & 12 & $60 \%$ & 7 & $35 \%$ \\
\hline MB & 3 & $15 \%$ & 4 & $20 \%$ \\
\hline BSH & 5 & $25 \%$ & 9 & $45 \%$ \\
\hline BSB & 0 & $0 \%$ & 0 & $0 \%$ \\
\hline
\end{tabular}

Adapun hasil persentase peningkatan kemampuan berhitung permulaan anak Siklus I secara rinci dapat dilihat pada grafik berikut ini:

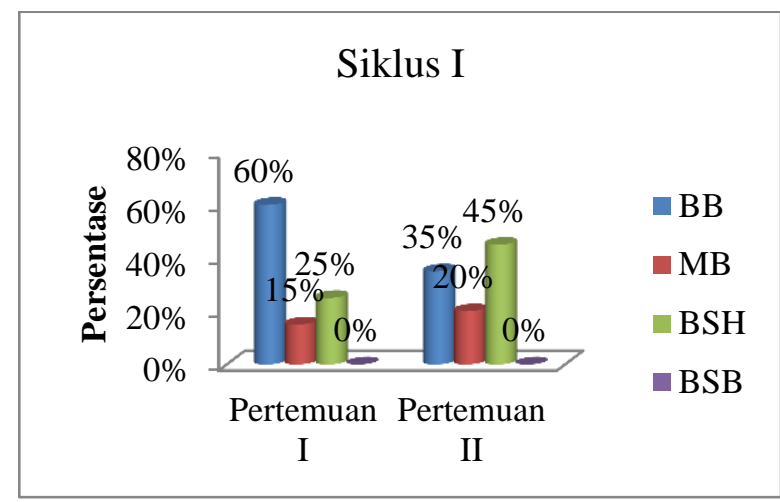

Grafik 2. Peningkatan Kemampuan Berhitung Permulaan Anak Siklus I

Dari hasil tersebut menunjukkan adanya peningkatan jumlah anak yang tuntas walaupun hasilnya belum optimal, pada kondisi awal tercatat hanya $15 \%$ anak yang mendapatkan penilaian berkembang sesuai harapan meningkat menjadi $45 \%$ pada pertemuan kedua Siklus I.

Siklus II
Kegiatan observasi dilakukan dengan mengamati ketika anak melakukan kegiatan kemudian mencatat peningkatan kemampuan berhitung anak sesuai indikator yang telah ditetapkan. Hasil observasi pertemuan pertama dengan menggunakan instrumen lembar observasi menyebutkan bahwa kemampuan berhitung permulaan dengan permainan balok angka pada anak Kelompok B sesuai data yang diperoleh adalah anak yang mendapat kriteria penilaian belum berkembang 4 anak (20\%), kriteria penilaian mulai berkembang 2 anak (10), kriteria penilaian berkembang sesuai harapan 14 anak (70\%). Hasil observasi peningkatan kemampuan berhitung permulaan anak dari Siklus I sebesar 9 anak menunjukkan persentase $45 \%$ meningkat menjadi 14 anak menunjukkan persentase $70 \%$ pada pertemuan pertama Siklus II di mana kemampuan berhitung permulaan anak berkembang sesuai harapan.

Pertemuan kedua pada Siklus II dapat diketahui dari hasil pengamatan terhadap anak dengan penilaian aspek kemampuan berhitung permulaan yang telah ditetapkan. Hasil analisis observasi terhadap peningkatan kemampuan berhitung permulaan anak pada pertemuan kedua Siklus II adalah 2 anak (10\%) 
dengan kriteria penilaian belum berkembang, 1 anak (5\%) mulai berkembang, dan 17 anak (85\%) dengan kriteria penilaian berkembang sesuai harapan. Terjadi peningkatan dari pertemuan pertama, yaitu 14 anak (70\%) menjadi 17 anak (85\%) pada pertemuan kedua.

Tabel 3 Peningkatan Kemampuan Berhitung Permulaan Anak Siklus II

\begin{tabular}{|c|c|c|c|c|}
\hline \multirow[b]{2}{*}{ Penilaian } & \multicolumn{2}{|c|}{ Pertemuan I } & \multicolumn{2}{|c|}{ Pertemuan II } \\
\hline & $\begin{array}{c}\text { Jumlah } \\
\text { anak }\end{array}$ & $\%$ & $\begin{array}{c}\text { Jumlah } \\
\text { anak }\end{array}$ & $\%$ \\
\hline BB & 4 & $20 \%$ & 2 & $10 \%$ \\
\hline MB & 2 & $10 \%$ & 1 & $5 \%$ \\
\hline BSH & 14 & $70 \%$ & 17 & $85 \%$ \\
\hline BSB & 0 & $0 \%$ & 0 & $0 \%$ \\
\hline
\end{tabular}

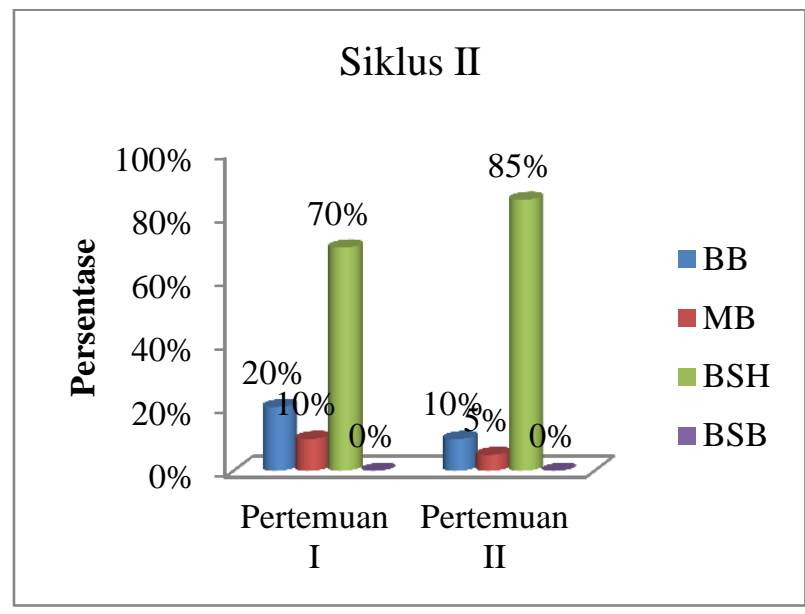

Grafik 3 Peningkatan Kemampuan Berhitung Permulaan Anak Siklus II

Berdasarkan hasil data di atas menunjukkan bahwa perbaikan yang dilakukan pada Siklus II mengalami peningkatan kemampuan berhitung pada Kelompok B TK Dharma Wanita 1
Ngadimulyo Kedu Temanggung Semester II Tahun Pelajaran 2017/2018.

Berdasarkan hasil observasi yang diperoleh dari tindakan Siklus II, kekurangan yang terjadi di Siklus I sudah dapat teratasi dengan baik, sehingga kemampuan berhitung anak menjadi lebih baik dari siklus sebelumnya. Persentase keberhasilan pada kemampuan berhitung anak telah mencapai persentase $85 \%$ pada pertemuan kedua Siklus II. Hasil tersebut telah melebihi dari indikator keberhasilan yaitu $80 \%$. Oleh karena itu, peningkatan kemampuan berhitung permulaan pada anak Kelompok B TK Dharma Wanita 1 Ngadimulyo Kedu Temanggung Semester II Tahun Pelajaran 2017/2018 tidak perlu dilanjutkan lagi.

\section{Pembahasan}

Hasil penelitian pada Siklus I dan Siklus II menunjukkan adanya peningkatan yang signifikan pada kemampuan berhitung permulaan anak kelompok B TK Dharma Wanita 1 Ngadimulyo Kedu Temanggung Semester II Tahun Pelajaran 2017/2018, peningkatan tersebut terjadi pada setiap pertemuan. Hal tersebut dapat dilihat dari peningkatan persentase kemampuan berhitung anak pada pratindakan sebesar $15 \%$ mengalami peningkatan pada Siklus I sebesar $45 \%$, sedangkan pada Siklus II mengalami 
peningkatan sebesar $85 \%$ dengan kriteria berkembang sesuai harapan dan telah mencapai indikator keberhasilan yaitu $80 \%$.

Tindakan pada penelitian ini dilakukan melalui kegiatan berhitung dengan permainan balok angka. Kegiatan pembelajaran dengan aspek mengenal konsep bilangan dengan mengurutkan angka pada balok angka, aspek mengenal konsep banyak sedikit dengan menunjukkan kumpulan benda yang jumlahnya banyak dan lebih sedikit, serta aspek menyebutkan hasil penambahan atau pengurangan dengan permainan balok angka dapat meningkatkan kemampuan berhitung permulaan pada anak. Kemampuan berhitung permulaan di TK memiliki tujuan untuk memperkenalkan anak dalam menggunakan hitungan.

Hasil penelitian ini sesuai dengan teori yang dikemukakan oleh Soetjiningsih (1995), bahwa tujuan dari permainan adalah untuk mengembangkan kemampuan menyamakan dan membedakan, mengembangkan kemampuan berbahasa, mengembangkan pengertian tentang berhitung, menambah, mengurangi, merangsang daya imajinasi dengan berbagai cara bermain pura-pura (sandiwara), membedakan benda dengan perabaan, menumbuhkan sportivitas, mengembangkan kepercayaan diri, mengembangkan sosialisasi atau bergaul dengan anak dan orang di rumah.

Setelah dilakukan analisa data, maka pengujian hipotesis menyimpulkan bahwa melalui permainan balok angka dapat meningkatkan kemampuan berhitung permulaan anak Kelompok B TK Dharma Wanita 1 Ngadimulyo Kedu Temanggung Semester II Tahun Pelajaran 2017/2018, hal ini ditunjukkan dengan adanya peningkatan yang signifikan pada kemampuan berhitung permulaan anak. Peningkatan persentase kemampuan berhitung permulaan anak pada pratindakan sebesar $15 \%$ mengalami peningkatan pada Siklus I sebesar $45 \%$, sedangkan pada Siklus II mengalami peningkatan sebesar $85 \%$ dengan kriteria berkembang sesuai harapan dan telah mencapai indikator keberhasilan yaitu $80 \%$. Anak telah mampu mengenal konsep bilangan dengan mengurutkan angka pada balok angka, aspek mengenal konsep banyak sedikit dengan menunjukkan kumpulan benda yang jumlahnya banyak dan lebih sedikit, serta aspek menyebutkan hasil penambahan atau pengurangan. Adapun ketuntasan hasil belajar anak dari kondisi pra siklus sampai dengan Siklus II dapat dilihat pada tabel berikut : 
Tabel 4 Peningkatan Kemampuan Berhitung Permulaan Anak Pra Siklus, Siklus I dan Siklus II

\begin{tabular}{ccccccc}
\hline Ketuntasa & \multicolumn{2}{c}{ Prasiklus } & \multicolumn{2}{c}{ Siklus I } & \multicolumn{2}{c}{ Siklus II } \\
n Hasil & Jml & $\%$ & Jm & $\%$ & Jm & $\%$ \\
Belajar & & & 1 & & 1 & \\
\hline BB & 15 & $75 \%$ & 7 & $35 \%$ & 2 & $10 \%$ \\
MB & 2 & $10 \%$ & 4 & $20 \%$ & 1 & $5 \%$ \\
BSH & 3 & $15 \%$ & 9 & $45 \%$ & 17 & $85 \%$ \\
BSB & 0 & $0 \%$ & 0 & $0 \%$ & 0 & $0 \%$ \\
\hline
\end{tabular}

Grafik 4. Peningkatan Kemampuan Berhitung Permulaan Anak Pra Siklus, Siklus I dan Siklus II

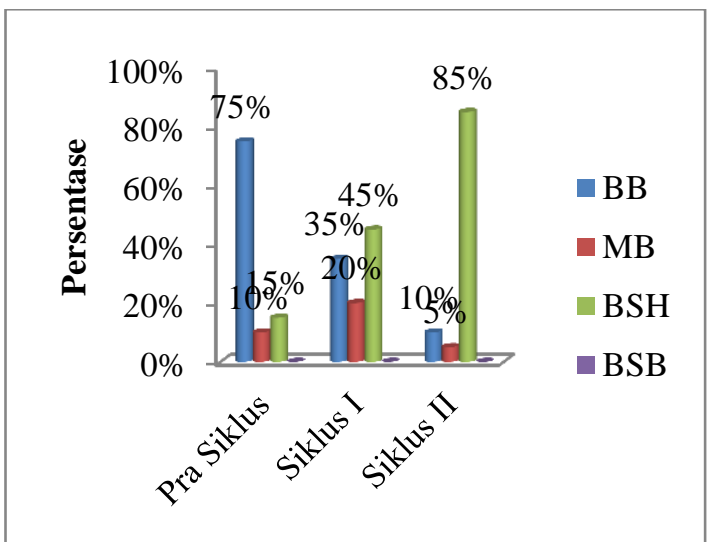

Dari hasil penelitian ini terbukti bahwa permainan balok angka dapat meningkatkan kemampuan berhitung permulaan anak. Pada indikator kinerja, peneliti menentukan $80 \%$ anak mampu meningkatkan kemampuan berhitungnya, pada Siklus II kemampuan hasil belajar anak pada aspek peningkatan berhitung permulaan anak mencapai nilai persentase $85 \%$ yang berarti telah mencapai nilai kriteria ketuntasan $80 \%$. Dengan demikian, hipotesis yang menyatakan kegiatan pembelajaran dengan permainan balok angka dapat meningkatkan kemampuan berhitung permulaan anak Kelompok B TK Dharma Wanita 1 Ngadimulyo Kedu Temanggung Semester II Tahun Pelajaran 2017/2018, terbukti kebenarannya.

Penelitian ini sesuai dengan pendapat Bredekamp \& Copple, anak usia 5-6 tahun dapat memilih balok berdasarkan warna, bentuk dan ukuran, anak dapat menyusun balok berdasarkan urutan paling kecil hingga paling besar atau berdasarkan urutan angka terkecil hingga angka terbesar. Anak secara akurat dapat menempel nama angka untuk serangkaian objek yang dihitung, sehingga anak mengerti makna angka dan pengenalannya.

Penelitian ini relevan dengan penelitian yang dilakukan oleh Vitri Purwanti, 2012. Hasil penelitian menunjukan bahwa terjadi peningkatan kemampuan membilang dengan media balok angka pada setiap siklusnya. Pada aspek pemahaman bilangan kondisi awal kemampuan anak $40 \%$ yang berkembang sangat baik, pada siklus I kemampuan anak meningkat menjadi 66\% dan meningkat lebih baik lagi pada siklus II yaitu $86 \%$. Aspek perbandingan, pada kondisi awal $37 \%$ yang berkembang sangat baik. Dan pada siklus I meningkat $66 \%$,dan pada siklus II meningkat lagi menjadi $86 \%$. Aspek analisis dan probabilitas pada kondisi awal anak ada 33\%, sedangkan 
pada siklus I meningkat menjadi $60 \%$, dan meningkat lebih baik lagi pada siklus II yaitu $86 \%$. Peningkatan ini melebihi dari indikator keberhasilan yang ingin dicapai yaitu $80 \%$.

\section{SIMPULAN}

Berdasarkan dari hasil penelitian yang telah dilaksanaan melalui beberapa tindakan dari Siklus I, Siklus II dan berdasarkan dari seluruh pembahasan serta analisis yang dilakukan dapat disimpulkan bahwa dengan permainan balok angka dapat meningkatkan kemampuan berhitung permulaan pada anak Kelompok B TK Dharma Wanita 1 Ngadimulyo Kedu Temanggung Semester II Tahun Pelajaran 2017/2018. Hal ini dibuktikan dengan indikator kemampuan berhitung anak meningkat dari $15 \%$ pada kondisi pra siklus menjadi $85 \%$ pada siklus II.

Proses implementasi permainan balok angka dalam pembelajaran berhitung permulaan yaitu peneliti memberikan penjelasan dan contoh cara penggunaan permainan balok angka, kemudian secara bersama-sama peneliti dan anak mempraktekkan permainan balok angka dengan mengurutkan angka yang tertera pada balok angka, menunjukkan kumpulan benda yang sama dan tidak sama, menyebutkan hasil penambahan dan pengurangan. Dalam setiap kegiatan peneliti selalu mengamati, memantau, membimbing, dan memberi motivasi kepada anak agar tumbuh rasa percaya diri dan semangat pada anak.

\section{DAFTAR PUSTAKA}

Depdiknas. (2004). Kurikulum Tingkat Satuan Pendidikan (KTSP). Jakarta : BP. Cipta Jaya.

Depdiknas. (2007). Permainan Berhitung Permulaan. Jakarta : Departemen Pendidikan Nasional.

Essa, L. Eva. (2001). Introduction to Early Childhood Education. Canada: Delmar Learning

Fadlillah, Muhammad. (2012). Desain Pembelajaran PAUD : Tinjauan Teoritik dan Praktik. Ar-Ruzz Media.

Hainstock, Elizabeth G. (1999). Metode Pengajaran Montessori untuk Anak Prasekolah. Jakarta: Pustaka Delapratasa.

Ismiyani, Ani. (2010). Fun Math with Children. Jakarta : PT. Elex Media Komputindo.

Kementerian Pendidikan Nasional Direktorat Jenderal Manajemen Pendidikan Dasar dan Menengah Direktorat Pembinaan TK dan SD. (2010). Pedoman Pengembangan Program Pembelajaran di TK.

Mahmud. (2011). Metode Penelitian Pendidikan. Bandung: Pustaka Setia

Masitoh, dkk. (2005). Pendekatan Belajar Aktif di Taman Kanak-kanak. Jakarta: Depdiknas Dikjen 
Pendidikan Tinggi Direktorat Pembinaan Pendidikan Tenaga Kependidikan Dan Ketenagaan Perguruan

Padmonodewo, Soemiarti. (2013) Pendidikan Anak Prasekolah. Jakarta : Rineka Cipta.

Semiawan, Conny. R. (2002). Belajar dan Pembelajaran dalam Taraf Usia Dini. Jakarta: PT Ikrar Mandiri Abadi

Setyono, Ariesandi. (2007). Mathemagics Cara Jenius Belajar Matematika. Jakarta : Gramedia Pustaka Utama.

Sriningsih, Nining. (2008). Pembelajaran Matematika Terpadu Untuk Anak Usia Dini. Bandung: Pustaka Sebelas.

Sudaryanti. (2006). Pengenalan Matematika Anak Usia Dini. Yogyakarta : UNY Press.

Sugiyono. (2009). Metode Penelitian Pendidikan. Bandung : Alfabeta

Suharsimi. Arikunto. (2007). Penelitian Tindakan Kelas. Jakarta : Bumi Aksara.

Sujiono, Yuliani Nurani. (2007). Konsep Dasar Pendidikan Anak Usia Dini. Jakarta: Indeks.

Susanto, Ahmad. (2011). Perkembangan Anak Usia Dini (Pengantar dalam Berbagai Aspek). Jakarta : Penerbit Kencana.

Suwandi, Sarwiji. (2010). Penelitian Tindakan Kelas (PTK) dan Penulisan Karya Ilmiah. Surakarta: Yuma Pustaka.
Suyanto, Slamet. (2005). Dasar-dasar Pendidikan AUD. Yogyakarta : Hikayat Publising.

Suyono. (2011). Belajar dan Pembelajaran. Bandung: PT Remaja Rosdakarya Offset

Yuniawati. (2011). Penerapan Pembelajaran Matematika dengan Strategi React untuk Meningkatkan Kemampuan Koneksi dan Representasi Matematik Siswa Sekolah Dasar. Jurnal Edisi Khusus No 2 ISSN 1412-565X 